11. Sharpe, William F. William F Sharpe: Selected Works. World Scientific-Nobel Laureate Series: Vol. 2. World Scientific. 2012. p. 712.

\title{
Reference:
}

1. Borshchevsky V. V. Inozemni investyciyi yak chynnyk regionalnogo rozvytku [Foreign investment as a factor of regional development]. Finansy Ukrayiny - Finance of Ukraine. 2003. Vol. 10. Pp. 108-117. [in Ukrainian].

2. Epifanova I. Y., Vojnarenko M. P. Upravlinnia investycijnoiu diyalnistiu promyslovyh pidpryiemstv [Management of investment activities of industrial enterprises]. Vinnytsia: VNTU, 2011. 188 p. [in Ukrainian].

3. Zagorodniy A. G., Vozniuk G. L. Menedzhment realnyh investycii [Management of real investments]. Lviv: Lviv Polytechnic National University Publishing House, 2005. 714 p. [in Ukrainian].

4. State Statistics Service of Ukraine. Official site. Retrieved from: http://www.ukrstat.gov.ua. (Accessed on 15 Nov 2020).

5. Peresada A. A., Smirnova O. O., Onykienko S. V., Liakhova O. O. Investuvannya [Investing]. Kyiv: KNEU, 2001.251 p. [in Ukrainian].

6. Chumachenko M. G. Sposoby i dzherela akumulyacii investycij u kraini ta umovy jih realizatsii [Methods and sources of accumulation of investments in the country and the conditions of their implementation]. Ekonomika ta derzhava - Economy and state. 2004. Vol. 3. Pp. 2-9. [in Ukrainian].

7. Alexander, G. J., Sharpe, W. F., Bailey, J. V. Fundamentals of investments. London: Pearson Educación. 2010. 896 p.

8. Behrens, Werner; Hawranek, Peter M. Manual for the preparation of industrial feasibility studies. Vienna: United Nations Industrial Development Organization, 1991. 387 p.

9. Gitman, L. J., Joehnk, M. D. Fundamentals of investing. London : Pearson College Div. 11th edition. 2010.597 p.

10. Kiyosaki, Robert T. The Business of the 21St Century. Manjul : Manjul Publishing House. 2012. 195 p.

11. Sharpe, William F. William F Sharpe: Selected Works. World Scientific-Nobel Laureate Series: Vol. 2. World Scientific. 2012. p. 712.

Дата подання публікації 22.12.2020p.

УДК 005.95 : 331.103.244 : 658

Сазонова Т.О., к.е.н., доцент, доцент кафедри менеджменту Sazonova T. Candidate of Economic Sciences, Associate Professor https://orcid.org/0000-0003-1454-5135 Пасічник С.М., здобувач вищої освіти Pasichnik E., student

\section{РОЛЬ КОМАНДНОГО МЕНЕДЖМЕНТУ В ЕФЕКТИВНІЙ ДІЯЛЬНОСТІ ПІДПРИЕМСТВА}

\author{
Полтавська державна аграрна академія
}

Сучасна практика управління персоналом організації ставить нові вимоги до планування, організації, координації, мотивації та контролю їх діяльності. Необхідність вирішувати повсякденні завдання виробничого та управлінського характеру новими методами та застосовуючи інноваційні інструменти впливу, робить актуальним об'єднання працівників за допомогою командного менеджменту. Управління командами працівників має свою специфіку, обмеження та правила ефективності. Також існують особливості управління командою дистанційно. Командний менеджмент дає можливість задовольнити потреби не лише особистісного зростання працівників, але й за рахунок цього підвищити ефективність діяльності підрозділу, організації в цілому. Специфіці управління персоналом на засадах командного менеджменту присвячена дана стаття. В ній розглянуті переваги формування та управління командами; особливості формування команди, яка буде працювати як on-line, так i off-line; правила та рекомендації для налагодження ефективної взаємодії в команді, незалежно від того чи вона буде працювати дистанційно, чи ні; визначені основні soft-skills, якими можуть оволодіти працівники, якщо керівництво застосовує командний менеджмент; специфіку застосування тімбілдінгу та його вплив на функціонування команди. Зроблена спроба довести, що особиста мотивація, ефективна координація та підтримка, з використанням в основному соціальних методів впливу, призводить до ефекту синергії відносно результативності діяльності персоналу та організації в цілому.

Ключові слова: командний менеджмент, команда, персонал, soft-skills, тімбілдінг, 


\title{
THE ROLE OF TEAM MANAGEMENT IN EFFECTIVE ACTIVITY ENTERPRISES
}

\author{
Poltava State Agrarian Academy
}

Today, personnel management in the organization requires the application of new approaches to planning, organization, coordination, motivation and control of their activities. The economic and social crisis caused, including the global COVID-19 pandemic, has created new demands on managers and all other workers. There is a need to solve familiar and new problems with innovative methods, using hitherto unusual for ordinary organizations methods, tools and management tools. All this makes the application of team management relevant. Managing teams that are small professional groups has its own specifics, limitations and rules of effectiveness. They differ from the rules of effective collective. Especially these features can be traced in the remote control of the team and its operation. This article is devoted to the specifics of personnel management on the basis of team management. An attempt is made to consider the advantages of creating teams, solving production and management tasks with their help. Features of formation and functioning of teams both on-line, and off-line are considered. Rules and recommendations for effective interaction in the team, regardless of whether it will work remotely or not. The basic soft-skills (communication skills; self-management; effective thinking skills and management skills) are defined. These competencies can be acquired by employees if management applies team management. The acquisition of these competencies will take place in a natural, gradual way. The more employees work in a team, the more they gain team experience, which forms the listed soft-skills. This set of competencies increases the value and competitiveness of employees in today's labor market. The article considers the role of teambuilding in the formation and functioning of an effective team. An attempt is made to prove that personal motivation, effective coordination and support, using mainly social methods of influence, leads to a synergy effect on the effectiveness of staff and the organization as a whole. Team management provides an opportunity to meet the needs not only of personal growth of employees, but also to increase the efficiency of the unit, the organization as a whole.

Keywords: team management, team, staff, soft-skills, team building, competence, remote control.

Постановка проблеми у загальному вигляді та ії зв'язок з важливими науковими i практичними завданнями. Управління персоналом $\epsilon$ центральним завданням менеджменту організації. Зважаючи на акумулювання в персоналі основних конкурентних переваг організації, пошук шляхів підвищення його ефективності та результативності залишається, й залишиться на майбутнє, актуальним завданням для менеджерів всіх рівнів. Разом з тим, на сьогоднішній день, управління персоналом ускладнилося наявною ситуацією, пов'язаною з соціальною, політичною та економічною кризою, що охопила не лише нашу країну, але й має глобальний характер. Зменшення фінансової ефективності функціонування підприємства призводе до скорочення фінансування сфери управління персоналу; соціальна та економічна нестабільність, зменшення реального рівня доходу створюють відчуття напруги та невпевненості у персоналу. Все це зумовлює необхідність пошуку нових активізаційних механізмів для персоналу, що не лише нададуть змогу зберегти та підвищити ефективність їх діяльності в сучасних умовах функціонування підприємства, але й сприятимуть нарощуванню його загальної ефективності.

Аналіз останніх досліджень, у яких започатковано вирішення проблеми. Проблеми формування команд, в т.ч. управлінських, особливості управління командами, труднощам, з якими стикаються при їх розвитку в тій чи іншій мірі розглянуті в працях, авторами яких є такі вітчизняні вчені, як Л.М. Карамушка, О.А. Філь [1], В.І. Барко, Ю.Б. Ірхін, П.П. Підюков [2], Г.В. Ложкін [3], С.Д. Максименко, В.О. Соловієнко [4]; зарубіжні вчені - М. Белбін, Д.А. Веттен, Дж.Р. Кемзенбер, Р. Кропп, К. Левіс-МакКлеар, П. Мучинські, К. Новак, Г. Паркер, Х.М. Пейро, А.П. Срошинін та інші. Дані вченідослідники розглядали особливості управління малими групами, процесу формування, розвитку, управління та розформування команд, командні ролі, які приймають на себе члени команд. Але проблема полягає в тому, що наразі склалася неординарна ситуація в сфері управління, виникли нові обмеження та специфічні умови взаємодії, комунікації, 
співпраці між працівниками. Все це потребує аналізу існуючих та формування нових підходів до управління командою.

Цілі статті. В даній статті зроблена спроба сформувати підходи до налагодження ефективного командного менеджменту, в тому числі, враховуючи специфіку дистанційної трудової діяльності.

Виклад основного матеріалу дослідження 3 повним обгрунтуванням отриманих наукових результатів. Основа ефективного менеджменту організації - $\epsilon$ високопрофесійна, висококваліфікована, згуртована команда, налаштована на досягнення організаційної мети 3 найменшими фінансовими, організаційними, психологічними витратами. Розглянемо більш детально переваги, які дає командний менеджмент (табл. 1).

Таблиця 1

Переваги командного менеджменту в сучасному менеджменті організацій [власна розробка на основі 5; 6]

\begin{tabular}{|c|c|}
\hline Ознака & Характеристика \\
\hline Відмінність від групи & $\begin{array}{l}\text { налаштованість на досягнення спільної мети та реалізація єдиної } \\
\text { стратегії, створює передумови для виконання поставлених завдань на } \\
\text { якісно новому рівні }\end{array}$ \\
\hline $\begin{array}{l}\text { Потенціал команди } \\
\text { придатний для... }\end{array}$ & $\begin{array}{l}\text { швидкого акумулювання та накопичення ресурсів, результативної } \\
\text { самоорганізації, самодисципліни для виконання поставленого завдання } \\
\text { та розформування }\end{array}$ \\
\hline Мотивація & команда $є$ засобом та інструментом для мотивації сама по собі \\
\hline Забезпеченість ресурсами & $\begin{array}{l}\text { передбачена вичерпна забезпеченість ресурсами різних видів, всіх, які } \\
\epsilon \text { необхідними для вирішення поставлених завдань }\end{array}$ \\
\hline Відповідальність & повна солідарна відповідальність за отримані результати \\
\hline Винагорода & $\begin{array}{l}\text { чіткість системи розподілу, виключно з урахуванням індивідуального } \\
\text { внеску }\end{array}$ \\
\hline Цінності & $\begin{array}{l}\text { передбачається безумовне прийняття та слідування } \\
\text { організації, команди }\end{array}$ \\
\hline $\begin{array}{l}\text { Розподіл функцій, обов’язків, } \\
\text { поточних завдань }\end{array}$ & $\begin{array}{l}\text { чіткий, зрозумілий, залежно від ролі працівника в команді, його } \\
\text { здібностей, схильностей та досвіду. Передбачає реальне прийняття на } \\
\text { себе даних зобов’язань та високу особисту відповідальність. } \\
\text { Взаємодоповнюючий склад групи }\end{array}$ \\
\hline Командні ролі & $\begin{array}{l}\text { передбачена наявність максимальної кількості позитивних ролей та } \\
\text { виключення працівників } 3 \text { негативними ролями (перевиховання, або } \\
\text { звільнення) }\end{array}$ \\
\hline Лідер & формальний та неформальний лідер - одна й та сама особа \\
\hline Рівень згуртованості & виключно високий; психологічно члени команди визнають один одного \\
\hline Тімбілдінг & природний прояв в повсякденній діяльності команди \\
\hline Креативність & умова існування команди та основна риса членів команди \\
\hline $\begin{array}{l}\text { Формула ефективності } \\
\text { команди }\end{array}$ & $\begin{array}{l}\text { 1+1+1=9 команда характеризується високим ступенем співпраці, } \\
\text { взаємодопомоги, підтримки - зростає ефективність діяльності команди. } \\
\text { Це є позитивним прикладом для інших команд, для організації в цілому. }\end{array}$ \\
\hline
\end{tabular}

Отже, командний менеджмент дає можливість досягти синергетичного ефекту, якого прагнуть отримати всі менеджери від власних підлеглих. Саме синергія, звісно позитивна, дає можливість добитися максимальної результативності, а дана властивість покладена в основу функціонування команди.

Кожний період функціонування організації характеризується вирішенням особливих завдань. Не зважаючи на те, що на перший погляд завдання можуть бути типовими, з плином часу підходи до їх вирішення, а також деякі складові завдань піддаються змінам. Не кажучи вже про нові, нетипові задачі. Якщо застосовувати при цьому проектний підхід, то стає очевидною необхідність створення команди. Сформуватися ефективна команда може й природнім шляхом, але основною 
передумовою в такому разі є наявність сильної корпоративної культури, що має значну «товщину». В іншому разі, формуючи команду, керівник має пересвідчитися в тому, що:

- члени команди є спеціалістами у тій сфері, в якій вони будуть виконувати завдання;

- існує психологічна сумісність між майбутніми членами команди;

- командні цілі об’єднують людей, а не налаштовують їх на конкуренцію;

- цілі командної роботи є дійсно значимі - тоді вони будуть самі по собі мотивувати членів команди щодо їх досягнення;

- цілі команди побудовані у відповідності зі SMART- критеріями;

- в умовах дистанційної роботи, у всіх членів команди є вільний доступ до необхідних інструментів трудової діяльності, засобів зв'язку.

При цьому дане завдання для керівника буде тим легше виконувати, чим частіше він буде використовувати проектний підхід в управлінні, а також у тому випадку, коли він добре буде знайомий із власними підлеглими: їх сильними та слабкими сторонами. В останньому випадку керівник має систематично застосовувати методи розвитку власного персоналу, щоб повністю забезпечити себе працівниками, здатними виконувати лише позитивні ролі, тоді й їх призначення в ту чи іншу команду буде нескладним завданням. Працювати за принципами командного менеджменту мають вміти не лише керівники, але й працівники. Це завдання має довгостроковий характер, але кожного разу, виконуючи його успішно, всі учасники закріплюють даний позитивний досвід та засвоюють уроки, що допомагають ще ефективніше та результативніше виконувати наступні завдання, досягаючи при цьому не лише організаційних, але й власних цілей.

Якщо працівники відчувають, що належать до певної, чітко окресленої команди, їх відповідальність за власний внесок у досягнення єдиної цілі зростає. Що потрібно зробити для того, щоб працівник відчув себе членом саме команди, а не колективу, бо колектив це більш невизначене утворення:

- чітко розподілити ролі, обов'язки, відповідальність;

- визначити періодичність зустрічей, нарад, «п’ятихвилинок» тощо;

- за умов дистанційної роботи, підтримувати постійний зв'язок за допомогою різних додатків, чатів - дозволяє підтримувати динаміку спілкування та швидкість вирішення питань, що постають перед певними членами команди, або командою в цілому. Головне - команда має користуватися одним чатом;

- встановити чіткі правила поведінки та взаємодії. При наявності віддаленої роботи - правила дистанційної роботи, режиму робочого дня (в більшості випадків від буде набагато гнучкішим, але робочий час не має перекриватися особистим);

- визначити реальні дедлайни та процедуру контролю;

- донести до членів команди, що конфліктів не вдасться уникнути, але вони мають бути виключно конструктивними, тобто в пріоритеті - спільна ціль. Конфліктні ситуації вирішувати виключно в присутності один одного, в т. ч. використовуючи платформи для дистанційного спілкування, типу Meet, Zoom тощо;

- налагодити швидку та адекватну винагороду - це в першу чергу стосується нематеріальної винагороди, яка піднімає самооцінку працівника, забезпечує задоволення мотиву в приналежності, повазі та самовираження;

- поєднати високий ступінь самостійності, автономності команди $з$ контролем менеджера лише у контрольних точках (відчуття довіри стимулює працівника бути більш дисциплінованим, звісно, в поєднанні з іншими способами «підкріплення»);

- запровадити реально ефективний зворотній зв'язок - замало надати широкі повноваження персоналу, необхідно постійно бути підтримкою для власних підлеглих, не лише у контрольних точках, але якщо у них виникають питання, проблеми, 
пропозиції, кожен член команди має бути впевнений, що він може звернутися до керівника і отримати необхідну підтримку, пораду тощо. В іншому випадку у персоналу буде створюватися враження, що на них просто «скинули» складне завдання. 3 якою метою? Сам керівник нездатний вирішити його - значить, він не може бути реальним лідером. Або ж, довести вищому керівництву, що даний персонал не здатний ефективно працювати - очевидна підстава для звільнення. Все це «вбиває» сутність командного менеджменту;

- в основу формування команди покласти принцип добровільного входження - в цьому випадку всі їі члени будуть добровільно приймати на себе відповідальність, та мати базисну мотивацію, а, отже, і дисциплінованість;

- забезпечити професійне зростання членів команди - це не означає, що всі вони, після успішного виконання поставлених завдань мають йти на підвищення, але у кожного 3 них має бути сформоване усвідомлення власного професійного зростання, удосконалення професійних якостей, просування на наступний щабель професіоналізму. За таких умов кожен працівник охоче буде долучатися до наступних проектів, адже, 3 кожним разом зростає його індивідуальна професійна цінність;

- за умови дистанційного управління, необхідне застосування CRM-системи, що дає можливість створити «внутрішній офіс» (Trello, Asana, YouGile, Microsoft Teams, Jira тощо). Дані системи, платформи дають можливість створити ефективний робочий простір: мають власні чати, можливість обміну файлами, відео- та аудіо- спілкування, примітки; можна презентувати, розміщувати задачі, слідкувати за виконанням, продуктивністю тощо;

- при дистанційному командному менеджменті ще важливіше досягти довірчих відносин. При цьому, на наш погляд, приклад має показати саме керівник власною відкритістю, в т.ч. демонстрацією, що він знаходиться у тому ж становищі, що всі інші ділитися фото власного домашнього офісу, домашнього улюбленця тощо.

Командний менеджмент налаштований на розвиток у рівній мірі як hard skills (професійні якості, які удосконалюються під час рішення професійних задач), так i soft skills (без яких не можлива ефективна ні формальна, ні неформальна взаємодія). Перелік soft skills, які сприяють зростанню конкурентоспроможності персоналу та організації в цілому наведемо за допомогою даних табл. 2.

Таблиця 2

Soft skills персоналу, що формуються при використанні командного менеджменту [сформовано на основі 7]

\begin{tabular}{|l|l|}
\hline \multicolumn{1}{|c|}{ Soft skills } & \multicolumn{1}{|c|}{ Прояв } \\
\hline $\begin{array}{l}\text { Комунікативні } \\
\text { навички }\end{array}$ & $\begin{array}{l}\text { вміння слухати, переконання і аргументація, нетворкінг: побудова та підтримка } \\
\text { бізнес-відносин, ведення переговорів, проведення презентацій, само презентація, } \\
\text { публічний виступ, командна робота, спрямованість на результат тощо }\end{array}$ \\
\hline Self-менеджмент & $\begin{array}{l}\text { управління емоціями, управління стресом, управління власним розвитком, } \\
\text { планування і цілепокладання, тайм менеджмент, рефлексія, ефективне } \\
\text { налагодження та використання зворотного зв'язку }\end{array}$ \\
\hline $\begin{array}{l}\text { Навички } \\
\text { ефективного } \\
\text { мислення }\end{array}$ & $\begin{array}{l}\text { системне мислення, креативне мислення, структурне мислення, логічне мислення, } \\
\text { пошук і аналіз інформації, формування та прийнятя рішень, проектне мислення, }\end{array}$ \\
\hline $\begin{array}{l}\text { Управлінські } \\
\text { навички }\end{array}$ & $\begin{array}{l}\text { управління викатегічне мислення (для керівників) } \\
\text { мотивування, контроль реалізації завдань, наставництво (розвиток співробітників) } \\
\text { виенторинг, коучинг, ситуаційне керівництво і лідерство, ведення нарад } 3 \\
\text { використанням інноваційних підходів, подача зворотного зв’язку, управління } \\
\text { проектами, управління змінами, делегування повноважень }\end{array}$ \\
\hline
\end{tabular}

Ефективний менеджмент сучасних організацій передбачає наявність soft skills у власних співробітників, і у керівників - у першу чергу, та їх перманентний розвиток. 
Яким чином командний менеджмент сприяє розвитку даних навичок?

По-перше, для їх розвитку необхідним є самостійне навчання - бажаючи бути ефективним членом команди та отримати вище перелічені бонуси від власної (та спільної) ефективної діяльності, працівники самомотивуються до самостійного навчання шляхом читання спеціалізованої літератури, відвідування тематичних блогів, вебінарів тощо.

По-друге, пошук та наявність ефективного зворотного зв'язку - дає можливість впевнитися у тому, що навичка успішно розвивається, тобто поведінка $є$ результативною, відносно певного (декількох) аспекту soft skills, або навпаки.

По-третє, навчання на досвіді інших (ментворкінг) - виокремлюючи найбільш ефективні моделі поведінки людини, що володіє високим рівнем розвитку даної компетентності, робота з наставником.

По-четверте, спеціальні завдання - завдання (в т. ч. обрані самостійно), що дозволяють розвивати певні навички, або навпаки ті, які нівелюють слабкі сторони.

По-п'яте, розвиток в процесі роботи - пошук, опанування найбільш ефективних моделей поведінки, при рішенні задач, доручених конкретному члену команди.

Отже, правила, методи, способи розвитку soft skills співвідносяться iз особливостями командного менеджменту та принципами результативної участі у командній роботі. Тому можна стверджувати, що розвиток soft skills $\epsilon$ природним «побічним» результатом застосування командного менеджменту. Фактично, ми маємо наслідки взаємодії за принципами стратегії «win-win».

В умовах соціальної напруги, в яких функціонують сучасні організації, в умовах невизначеності, нестабільності та зниження економічної ефективності функціонування (характерної для більшості комерційних організацій на сьогодні), важливим $є$ також підтримка та згуртування персоналу, надання їм відчуття захищеності та психологічного комфорту максимально, на скільки це можливо в індивідуальних умовах. Командний менеджмент передбачає тімбілдінг на рівні з чітким розподілом завдань, прозорим контролем тощо. Тімбілдинг - це особливий світ можливостей, нова реальність, де незвичайні, нестандартні, непрогнозовані обставини дозволяють відкриватися людям 3 несподіваних сторін [8]. Він дає можливості вирішити базові проблеми командотворення та сучасного трудового та особистісного існування персоналу:

- більш тісне знайомство співробітників в неформальній обстановці;

- посилення ефективності командної роботи;

- підвищення рівня взаємодії, згуртування колективу;

- оцінка ролі кожного члена команди;

- виявлення лідерів, аутсайдерів;

- розширення навичок вирішення нестандартних ситуацій;

- підвищення мотивації на досягнення колективних цілей;

- зняття стресу, втоми;

- можливість для співробітників відчути себе в новій ролі.

Таким чином, ми можемо спостерігати не лише позитивний вплив тімбілдінгу для функціонування команди, але й для особистісного розвитку кожного іiі члену, психологічного розвантаження, креативного ставлення до ситуації тощо.

Висновки. Отже, спираючись на проведене дослідження, аналіз умов діяльності сучасних організацій, можемо констатувати доцільність застосування командного менеджменту для активізації персоналу, формування його мотиваційного вектору та підвищення рівня лояльності працівників, без значних фінансових затрат, спираючись більше на соціальні методи управління. Командний менеджмент дає змогу розвити у персоналу широкий набip hard-skills та soft-skills. Цей комплекс компетентностей підвищує цінність, конкурентоспроможність працівників на сучасному ринку праці. 
Вони стають більш універсальними та сучасними, що створює потенційні передумови для швидкого працевлаштування, навіть за умови втрати наявної роботи. Все це не лише мотивує персонал до розвитку, але й дає можливість задовольнити широкий спектр мотивів згідно теорії А. Маслоу, що, в свою чергу, формує стійку мотивацію до високоефективної діяльності. Таким чином, підвищуючи індивідуальну результативність, налаштовуючись на досягнення в першу чергу організаційних цілей, персонал формує передумови для зростання ефективності організації.

\section{Список бібліографічного опису}

1. Карамушка Л. М., Філь О. А. Формування конкурентоздатної управлінської команди (на матеріалі діяльності освітніх організацій): Монографія. Київ: Фірма «ІНКОС», 2007. 268 с.

2. Барко В. І., Ірхін Ю. Б., Підюков П. П. Психологія управління командою міліцейського підрозділу : навч. посіб. Київ : РВЦ НАВСУ: Київ. юрид. ін-т МСВ України, 2006. 228 с.

3. Ложкин Г. В., Повякель Н. И. Практическая психология конфликта. 2-е издание, стереотипное. Киев : МАУП, 2002. $196 \mathrm{c}$.

4. Максименко С. Д., Соловієнко В. О. Загальна психологія: навч. посіб. Київ : 2000. URL: http://univer.nuczu.edu.ua/tmp_metod/875/Maksimenko_S.D._-_Zagal\%27na_psihologiya.pdf (дата звернення 05.12.2020). 5. Муха Р. А. Команда, іï сутність та особливості розвитку. Ефективна економіка. 2015. № 8. URL: http://www.economy.nayka.com.ua/?op=1\&z=4253 (дата звернення 10.12.2020).

6. Радугин А., Радугин К. Введення в менеджмент: Соціологія організацій та управління. Воронеж, 2005. 185 с.

7. Шипилов В. Перечень навыков soft-skills и способы их развития. URL: https://www.cfin.ru/management/people/dev_val/soft-skills.shtml (дата звернення 12.12.2020).

8. Командный менеджмент - новая реальность управления бизнесом. Часть 2. URL: https://hr-elearning.ru/komandnyymenedzhment-teambilding-2/ (дата звернення 12.12.2020).

\section{References}

1. Karamushka L. M., Fil O. A. Formuvannia konkurentozdatnoi upravlinskoi komandy (na materiali diialnosti osvitnikh orhanizatsii): Monohrafiia. Kyiv: Firma «INKOS», 2007. 268 p. [in Ukraine]

2. Barko V. I., Irkhin Yu. B., Pidiukov P. P. Psykholohiia upravlinnia komandoiu militseiskoho pidrozdilu : Navch. posib. Kyiv : RVTs NAVSU: Kyiv. yuryd. in-t MSV Ukrainy, 2006. 228 p . [in Ukraine]

3. Lozhkin G. V., Povyakel' N. I. Prakticheskaya psihologiya konflikta. 2-e izdanie, stereotipnoe. Kiev : MAUP, 2002.196 p. [in Russian]

4. Maksymenko S. D., Soloviienko V. O. Zahalna psykholohiia: navch. posib. Kyiv : 2000. Available at: http://univer.nuczu.edu.ua/tmp_metod/875/Maksimenko_S.D._-_Zagal\%27na_psihologiya.pdf (accessed 05.12.2020) [in Ukraine]

5. Mukha R. A. Komanda, yii sutnist ta osoblyvosti rozvytku. Efektyvna ekonomika. 2015. No 8. Available at: http://www.economy.nayka.com.ua/?op=1\&z=4253 (accessed 10.12.2020) [in Ukraine]

6. Radugin A., Radugin K. Vvedennya v menedzhment: Sociologiya organizacij ta upravlinnya. Voronezh, 2005. 185 p. [in Russian]

7. Shipilov V. Perechen' navykov soft-skills i sposoby ih razvitiya. Available at: https://www.cfin.ru/management/people/dev_val/soft-skills.shtml (accessed 12.12.2020) [in Russian]

8. Komandnyj menedzhment - novaya real'nost' upravleniya biznesom. Vol. 2. Available at: https://hrelearning.ru/komandnyy-menedzhment-teambilding-2/ (accessed 12.12.2020) [in Russian]

Дата подання публікації 28.12.2020 p. 